\title{
Article
}

\section{YouTube as a Source of Influenza Vaccine Information in Spanish}

\author{
Ignacio Hernández-García ${ }^{1,2, *(\mathbb{D})}$ and Teresa Giménez-Júlvez ${ }^{3}$ \\ 1 Department of Preventive Medicine and Public Health, Lozano Blesa University Clinical Hospital \\ of Zaragoza, Calle San Juan Bosco 15, 50009 Zaragoza, Spain \\ 2 Health Services Research Group of Aragon (GRISSA), Aragon Institute for Health Research (IISA), \\ Calle San Juan Bosco 15, 50009 Zaragoza, Spain \\ 3 Department of Preventive Medicine and Public Health, Miguel Servet University Hospital of Zaragoza, \\ Paseo Isabel la Católica 1, 50009 Zaragoza, Spain; tgimenez@salud.aragon.es \\ * Correspondence: ihernandezga@salud.aragon.es
}

Citation: Hernández-García, I.;

Giménez-Júlvez, T. YouTube as a Source of Influenza Vaccine Information in Spanish. Int. J. Environ. Res. Public Health 2021, 18, 727.

https://doi.org/10.3390/ijerph18020727

Received: 28 November 2020

Accepted: 14 January 2021

Published: 15 January 2021

Publisher's Note: MDPI stays neutral with regard to jurisdictional clai$\mathrm{ms}$ in published maps and institutional affiliations.

Copyright: (C) 2021 by the authors. Licensee MDPI, Basel, Switzerland. This article is an open access article distributed under the terms and conditions of the Creative Commons Attribution (CC BY) license (https:// creativecommons.org/licenses/by/ $4.0 /)$.

\begin{abstract}
Our objective was to analyze the information in Spanish on YouTube about the influenza vaccine. In August 2020, a search was conducted on YouTube using the terms "Vacuna gripe", "Vacuna influenza", and "Vacuna gripa". Associations between the type of authorship, country of publication, and other variables (such as tone, hoaxes, and vaccination recommendations) were studied via univariate analysis. A total of 100 videos were evaluated; $57.0 \%$ were created in Mexico $(24.0 \%)$, Argentina $(17.0 \%)$, and Spain $(16.0 \%)$, and $74.0 \%$ were produced by mass media or health professionals. Positive messages were detected in $65.0 \%$. The main topics were the benefits of the vaccine $(59.0 \%)$ and adverse effects $(39.0 \%)$. Hoaxes were detected in 19 videos. User-generated content, compared to that of health professionals, showed a higher probability of hoaxes (odds ratio $(\mathrm{OR})=15.56)$, a lower positive tone $(\mathrm{OR}=0.04)$, and less evidence of recommendations to vaccinate pregnant individuals $(\mathrm{OR}=0.09)$ and people aged $60 / 65$ or older. Videos published in Spain, in comparison with those from Hispanic America, presented significant differences in the positive tone of their messages $(\mathrm{OR}=0.19)$ and in the evidence of the benefits of vaccination $(\mathrm{OR}=0.32)$. A higher probability of hoaxes was detected in videos from Spain and the USA. Information in Spanish about the influenza vaccine on YouTube is usually not very complete. Spanish health professionals are urged to produce pro-vaccination videos that counteract hoaxes, and users in Hispanic America should be advised to consult videos produced in Hispanic American countries by health professionals to obtain reliable information.
\end{abstract}

Keywords: influenza vaccine; YouTube; Spanish; information; hoaxes; evaluation

\section{Introduction}

YouTube is the second biggest search engine and the second most visited website in the world [1]. Every day, YouTube exceeds 2 billion views, with the average user spending at least $15 \mathrm{~min}$ on the website [2]. Moreover, YouTube is an increasingly important source of health information and has the capacity to influence its users, e.g., regarding their vaccination habits [3]. For this reason, a strategy proposed by several scientific societies to increase influenza vaccination coverage is to use social networks to spread official indications and raise awareness of the importance of the vaccine [4].

However, the information shown on YouTube often lacks scientific rigor because anyone can upload such content [2]. For this reason, YouTube contains many videos that may be misleading [5].

Appropriate YouTube content can benefit health organizations by ensuring that the population properly implements measures to control the spread of infectious diseases; however, misleading videos can contribute to a failure to contain these diseases [6]. In particular, several authors have suggested that the spread of disinformation on the web 
may be associated with declines in vaccination coverage among the population [7,8]. For this reason, monitoring the information available in the media, such as YouTube, could be useful in assessing the level of vaccine hesitation and planning and conducting effective information campaigns [7].

In this context, infodemiological studies are necessary, since they can provide valuable insights into health-related behaviors of populations. Infodemiology is the science of distribution and determinants of information on the Internet or in a population, and it has the aim of informing public health and public policy $[9,10]$. Examples of infodemiology applications include the identification and monitoring of public-health-relevant publications on the Internet, measuring information diffusion, and analyzing how people search and navigate on the Internet for health-related information as well as how they communicate and share this information $[9,10]$.

Multiple authors have carried out infodemiological studies that analyzed the characteristics of YouTube videos providing information about several vaccines [8,11-17]. However, information in Spanish about the influenza vaccine has been poorly studied because, among other things, scholars have not analyzed the incorrect information available on YouTube about this vaccine [18].

This research was carried out to analyze the information in Spanish on YouTube about the influenza vaccine. In particular, we addressed the following research questions (RQ):

- RQ 1: What are the general characteristics of the videos?

- RQ 2: What are the temporal distribution and the positive tone of the videos?

- RQ 3: What is the information related to the influenza vaccine discussed in the videos?

- RQ 4: What are the hoaxes and conspiracy theories related to the influenza vaccine discussed in the videos, and when and by whom were such videos published?

In addition, under the hypothesis that the variables type of authorship of the video and country of publication are related to certain characteristics of the videos, we addressed the following RQ:

- RQ 5: Is there any relationship between the type of authorship of the video and the year of publication, number of views/likes/dislikes/comments, duration, type of publication, positive tone of the message, and information discussed regarding the influenza vaccine?

- RQ 6: Is there any relationship between the country of publication of the video and the year of publication, number of views/likes/dislikes/comments, duration, type of publication, positive tone of the message, and information discussed regarding the influenza vaccine?

\section{Materials and Methods}

On 26 August 2020, a cross-sectional study of the data was conducted by entering the terms "Vacuna gripe", "Vacuna influenza", and "Vacuna gripa" into the YouTube search engine. The videos were sorted according to the number of their views. After applying the inclusion criteria (published since 1 January 2015) and the exclusion criteria (not available for viewing, not providing information on the influenza vaccine, language other than Spanish, and duplicated video), we selected the 100 most viewed videos. We decided to limit our analysis to the 100 most viewed videos since this is a common and accepted procedure when investigating YouTube videos [19-21].

The full name of the video, its URL (Uniform Resource Locator), and the information corresponding to the following variables were recorded: date of publication, country of publication, number of views, number of likes, number of dislikes, number of comments, duration, type of publication, and type of authorship (representing the person or organization that produced the video, classified into 4 categories: "mass media", including television and journals; "health professionals", including healthcare workers, medical centers, and official public health organizations; "user-generated content", a lay person's opinion about the issue; and "others", videos that did not belong to any other category $[3,22])$. 
The videos were categorized according to message tone, adopting a classification used previously in other studies $[3,14,15,23]$ : "positive", vaccination is clearly recommended, i.e., the central message of the video supports vaccination, portraying it positively (e.g., described the benefits and safety of the influenza vaccine, described vaccination as a social good, or encouraged people to receive such vaccine); "negative", arguments are put forward against vaccination, i.e., the main message portrays vaccination negatively (e.g., emphasized the risk of vaccination, advocated against vaccination, promoted distrust in vaccine science, made allegations of conspiracy or collusion between supporters of vaccination and manufacturers); "ambiguous", information is given for and against the vaccine, i.e., a beneficial or social good is countered by negative experiences; and "neutral", there are no statements related to either approval or disapproval of the vaccine. Moreover, we recorded whether the videos provided information on the benefits, adverse effects, costs, dosage, and influenza vaccination recommendations for persons 60/65 years of age or older; pregnant women; healthcare workers; children; persons with chronic cardiovascular diseases; and those with chronic lung diseases, diabetes mellitus, obesity, cancer, infection by human immunodeficiency virus, and chronic kidney disease. Hoaxes and conspiracy theories related to the influenza vaccine were also recorded.

For assessing the message tone, 2 authors (I.H.-G. and T.G.-J.) independently viewed the selected videos and determined the tone of their message, according to the previously described definitions of "positive", "negative", "ambiguous", or "neutral" tone. Both authors had previous experience in assessing the tone of the YouTube videos message in relation to vaccines [14]. A concordance analysis was performed between the two using the Kappa index, without obtaining any discrepancies (kappa $=1.0$ ).

A descriptive analysis of the variables was performed; quantitative variables were expressed as the median (range), while qualitative variables were expressed as the absolute $(n)$ and relative (\%) frequencies. The associations between the type of authorship (categorized in mass media, user-generated content, health professionals, and others) and the year of publication, type of publication, tone of the message (categorized in positive and other), and information discussed regarding the influenza vaccine were studied. For this purpose, a chi-squared test or Fisher's exact test were used. The magnitude of the associations was quantified with the odds ratio (OR), and a 95\% confidence interval (CI) was obtained with a univariate logistic regression analysis. The associations between the type of authorship (categorized in mass media, user-generated content, health professionals, and others) and the video duration, number of views, number of likes, number of dislikes, and number of comments were studied. After using the Kolmogorov-Smirnov test to ensure that no variables followed a normal distribution, we compared the median values with a Mann-Whitney $U$-test.

The associations between the country of publication (categorized in Spain, the United States of America, Hispanic American countries, and others/unknown) and the year of publication, type of publication, tone of the message (categorized in positive and other), and information discussed regarding the influenza vaccine were studied. For this purpose, a chi-squared test or Fisher's exact test were used. The magnitude of the associations was quantified with the odds ratio (OR) and a 95\% confidence interval (CI) was obtained with a univariate logistic regression analysis. The associations between the country of publication (categorized in Spain, the United States of America, Hispanic American countries, and others / unknown) and the video duration, number of views, number of likes, number of dislikes, and number of comments were studied. For this purpose, the median values were compared with a Mann-Whitney U-test. Moreover, a chi-squared test or Fisher's exact test were used to study the association between the year of publication of the video and the positive tone of the message, as well as the detection of hoaxes/conspiracy theories.

The level of statistical significance for comparison of the hypotheses was established at $p<0.05$. All the statistical analyses were performed using SPSS v25 and EpiInfo. 


\section{Results}

The 100 most widely viewed videos, published between 1 January 2015 and 26 August 2020, were analyzed. There were 55 videos excluded and replaced: 4 due to irrelevance (not about the influenza vaccine), 6 that were not available for viewing, and 45 as triplicated videos.

\subsection{RQ 1: What Are the General Characteristics of the Videos?}

Of the 100 videos, the majority $(n=70,70.0 \%)$ were produced in Mexico $(24.0 \%)$, Argentina $(17.0 \%)$, Spain $(16.0 \%)$, and Chile $(13.0 \%)$ (Table 1$)$. The median length (range) was $187.5 \mathrm{~s}(10-4769)$, and the number of views, likes, dislikes and comments were, respectively, 10,553.5 (2936-294,969), $69.5(0-10,089), 11.5(0-546)$, and 16.5 (0-2072). With regard to the type of authorship and publication, $74.0 \%$ of the videos were produced by mass media or health professionals, and $70.0 \%$ of the videos were news pieces or material created by a user (Table 1).

Table 1. General characteristics of the 100 videos.

\begin{tabular}{|c|c|}
\hline Characteristics & Frequency, $n(\%)$ \\
\hline \multicolumn{2}{|l|}{ Country of publication } \\
\hline Mexico & $24(24.0)$ \\
\hline Argentina & $17(17.0)$ \\
\hline Spain & $16(16.0)$ \\
\hline Chile & $13(13.0)$ \\
\hline The United States of America & $11(11.0)$ \\
\hline Colombia & $3(3.0)$ \\
\hline Peru & $3(3.0)$ \\
\hline Nicaragua & $2(2.0)$ \\
\hline Costa Rica & $2(2.0)$ \\
\hline France & $2(2.0)$ \\
\hline Paraguay & $1(1.0)$ \\
\hline Panama & $1(1.0)$ \\
\hline Canada & $1(1.0)$ \\
\hline Russia & $1(1.0)$ \\
\hline Unknown & $3(3.0)$ \\
\hline \multicolumn{2}{|l|}{ Type of authorship } \\
\hline Mass media & $51(51.0)$ \\
\hline Health professionals & $23(23.0)$ \\
\hline User-generated content & $20(20.0)$ \\
\hline Others & $6(6.0)$ \\
\hline \multicolumn{2}{|l|}{ Type of publication } \\
\hline News & $36(36.0)$ \\
\hline Material created by the user & $34(34.0)$ \\
\hline Interviews & $18(18.0)$ \\
\hline Advertisements & $8(8.0)$ \\
\hline Conferences & $2(2.0)$ \\
\hline Documentaries & $2(2.0)$ \\
\hline
\end{tabular}

\section{2. $R Q$ 2: What Are the Temporal Distribution and the Positive Tone of the Videos?}

Among the most widely viewed YouTube videos, almost half $(n=48 ; 48.0 \%)$ were published in the years 2019 and 2020 (Table 2). In total, 65.0\% of the videos provided positive messages regarding the use of the vaccine, while negative, neutral, or ambiguous messages were in $16.0 \%, 15.0 \%$, and $4.0 \%$ of the videos, respectively.

Among the 65 videos with a positive tone, $4(6.2 \%)$ were published in 2015, $8(12.3 \%)$ in 2016, $7(10.8 \%)$ in 2017, $11(16.9 \%)$ in 2018, $15(23.0 \%)$ in 2019, and $20(30.8 \%)$ in 2020 $(p>0.05)$. 
Table 2. Year of publication of the 100 videos.

\begin{tabular}{cc}
\hline Year of Publication & Frequency, $\boldsymbol{n} \mathbf{( \% )}$ \\
\hline 2015 & $9(9.0)$ \\
2016 & $11(11.0)$ \\
2017 & $14(14.0)$ \\
2018 & $18(18.0)$ \\
2019 & $20(20.0)$ \\
2020 & $28(28.0)$ \\
\hline
\end{tabular}

\section{3. $R Q$ 3: What Is the Information Related to the Influenza Vaccine Discussed in the Videos?}

The most frequent information in the videos was about the benefits of the vaccine $(59.0 \%)$, adverse effects $(39.0 \%)$, recommendations for any trimester of pregnancy $(36.0 \%)$, and recommendations for people aged 65 years or older (27.0\%) (Table 3 ).

Table 3. Information related to the influenza vaccine discussed in the videos.

\begin{tabular}{|c|c|c|}
\hline Information Related to the Influenza Vaccine & $\begin{array}{c}\text { Discussed, } \\
n(\%)\end{array}$ & $\begin{array}{c}\text { Not Discussed, } \\
n(\%)\end{array}$ \\
\hline Benefits of the vaccine & $59(59.0)$ & $41(41.0)$ \\
\hline Adverse effects of the vaccine & $39(39.0)$ & $61(61.0)$ \\
\hline Recommendations for any trimester of pregnancy & $36(36.0)$ & $64(64.0)$ \\
\hline Recommendations for people aged 65 years of age or older & $27(27.0)$ & $73(73.0)$ \\
\hline Recommendations for people with chronic lung diseases & $26(26.0)$ & $74(74.0)$ \\
\hline Recommendations for people with diabetes mellitus & $21(21.0)$ & $79(79.0)$ \\
\hline Recommendations for people with chronic cardiovascular diseases & $20(20.0)$ & $80(80.0)$ \\
\hline Hoaxes and conspiracy theories & $19(19.0)$ & $81(81.9)$ \\
\hline Recommendations for healthcare workers & $18(18.0)$ & $82(82.0)$ \\
\hline Costs of the vaccine & $18(18.0)$ & $82(82.0)$ \\
\hline Recommendations for children of 6 months to 5 years & $17(17.0)$ & $83(83.0)$ \\
\hline Recommendations for people with cancer & $14(14.0)$ & $86(86.0)$ \\
\hline Description of the dosage & $14(14.0)$ & $86(86.0)$ \\
\hline Recommendations for people with obesity & $13(13.0)$ & $87(87.0)$ \\
\hline Recommendations for people of 60 or more years & $11(11.0)$ & $89(89.0)$ \\
\hline Recommendations for all people older than 6 months & $11(11.0)$ & $89(89.0)$ \\
\hline Recommendations for children aged 6 months to 2 years & $10(10.0)$ & $90(90.0)$ \\
\hline Recommendations for people with HIV a & $9(9.0)$ & $91(91.0)$ \\
\hline Recommendations for people with chronic kidney disease & $7(7.0)$ & $93(93.0)$ \\
\hline Recommendations for pregnant women from 13 weeks of gestation & $5(5.0)$ & $95(95.0)$ \\
\hline Recommendations for children aged 6 months to 6 years & $3(3.0)$ & $97(97.0)$ \\
\hline Recommendations for children aged 6 months to 10 years & $3(3.0)$ & $97(97.0)$ \\
\hline
\end{tabular}

a HIV: human immunodeficiency virus.

3.4. RQ 4: What Are the Hoaxes and Conspiracy Theories Related to the Influenza Vaccine Discussed in the Videos, and When and by Whom Were Such Videos Published?

Hoaxes and conspiracy theories were detected in 19 videos (19.0\%) (14 corresponded to user-generated content, 3 videos were produced by health professionals, and 2 were released by mass media). In particular, 12 videos indicated that the influenza vaccine is not safe, because, among other factors, it is formed by formaldehyde and thiomerosal (derived from mercury), which are neurotoxic and have harmful effects on people's health, or because influenza vaccination is associated with autism, Alzheimer's disease, infant mortality, autoimmune diseases, or the cause of coronavirus disease 2019 (COVID-19). Moreover, seven videos indicated that the influenza vaccine is totally ineffective and constitutes a scam by the big pharmaceutical industries to make money from vulnerable people. Three videos specified that it is better to drink certain infusions to avoid influenza than to get vaccinated; two videos indicated that the influenza vaccine is used to control our minds; and two videos explained that influenza vaccines spread influenza (Table 4).

The three videos produced by health professionals who perpetuated hoaxes dealt with the following topics: the influenza vaccine can produce influenza; the vaccine is contraindicated in pregnant women, those with chronic degenerative or chronic infectious 
diseases, or those who have some type of immunosuppression; and the influenza vaccine causes fibromyalgia and multiple sclerosis.

Among the 19 videos with hoaxes and conspiracy theories, $2(10.5 \%)$ were published in 2015, 3 (15.8\%) in 2016, 3 (15.8\%) in 2017, 6 (31.6\%) in 2018, 2 (10.5\%) in 2019, and 3 $(15.8 \%)$ in $2020(p>0.05)$.

Table 4. Hoaxes and conspiracy theories detected in the videos.

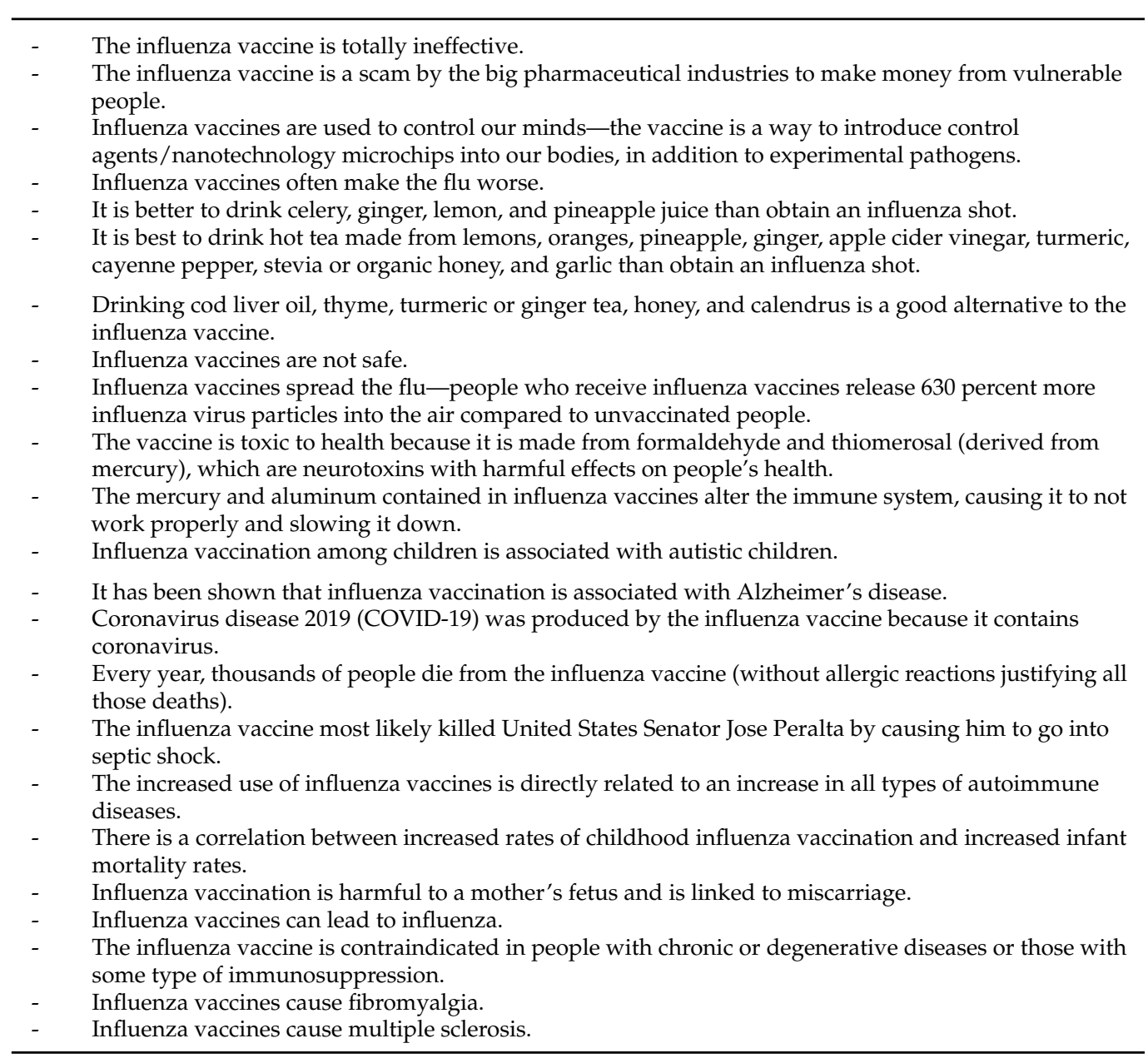

3.5. RQ 5: Is There Any Relationship between the Type of Authorship of the Video and the Year of Publication, Number of Views/Likes/Dislikes/Comments, Duration, Type of Publication, Positive Tone of the Message, and Information Discussed Regarding the Influenza Vaccine?

According to the type of authorship, in the univariate analysis, the user-generated content, compared to the videos produced by health professionals, presented significant differences in their number of likes (a median (range) of 319.5 (0-3911) for the user-generated content and of $52(3-1074)$ in those produced by health professionals $(p=0.006))$; number of comments (median (range) of $34(0-519)$ for user-generated contents and $3(0-347)$ in those produced by health professionals $(p=0.031))$; positive tone of the message (OR: $0.04(95 \%$ CI: 0.01-0.19)) (Table 5); the presence of hoaxes (OR: 15.56 (95\% CI: 3.32-72.93)); evidence of benefits from the vaccine (OR: 0.06 (95\% CI: 0.01-0.29)); and recommendations for pregnant women (OR: 0.09 (95\% CI: 0.02-0.46)), children, and persons aged 60/65 years or older (Table 6). There were also differences in the type of authorship and the frequency with which the video provided information on the recommendation to vaccinate all persons older than 6 months (Table 6).

In addition, videos produced by health professionals, compared to those of the mass media, showed significant differences in their duration (median (range), with 105 (10-1901) 
seconds in those produced by health professionals and 198 (35-4665) seconds in those of the mass media $(p=0.034))$. No other significant differences were detected $(p>0.05)$.

Table 5. Type of authorship and tone of the message.

\begin{tabular}{cccccc}
\hline \multirow{2}{*}{ Tone } & Type of Authorship & $\begin{array}{c}\text { Available, } \\
\boldsymbol{n}(\mathbf{\%})\end{array}$ & $\begin{array}{c}\text { Unavailable, } \\
\boldsymbol{n}(\mathbf{\%})\end{array}$ & OR (95\% CI) $^{\mathbf{a}}$ & $\boldsymbol{p}$ \\
\hline \multirow{3}{*}{$\begin{array}{c}\text { Positive tone of the } \\
\text { message }\end{array}$} & Mass media & $36(55.4)$ & $15(42.9)$ & $0.36(0.09-1.39)$ & 0.155 \\
\cline { 2 - 6 } & User-generated content & $4(6.2)$ & $16(45.7)$ & $0.04(0.01-0.19)$ & 0.000 \\
\cline { 2 - 7 } & Others & $5(7.7)$ & $1(2.9)$ & $0.75(0.06-8.83)$ & 1.000 \\
\cline { 2 - 7 } & Health professionals & $20(30.7)$ & $3(8.5)$ & 1 & \\
\hline
\end{tabular}

${ }^{\text {a }}$ OR $(95 \% \mathrm{CI})$ : odds ratio ( $95 \%$ confidence interval).

Table 6. Type of authorship and information discussed regarding the influenza vaccine.

\begin{tabular}{|c|c|c|c|c|c|}
\hline $\begin{array}{l}\text { Information Regarding } \\
\text { Influenza Vaccine }\end{array}$ & Type of Authorship & $\begin{array}{l}\text { Available, } \\
n(\%)\end{array}$ & $\begin{array}{c}\text { Unavailable, } \\
n(\%)\end{array}$ & OR $(95 \% \mathrm{CI})^{\mathrm{a}}$ & $p$ \\
\hline \multirow{4}{*}{ Benefits of the vaccine } & Mass media & $35(59.3)$ & $16(39.1)$ & $0.77(0.26-2.33)$ & 0.648 \\
\hline & User-generated content & $3(5.1)$ & $17(41.5)$ & $0.06(0.01-0.29)$ & 0.000 \\
\hline & Others & $4(6.8)$ & $2(4.9)$ & $0.71(0.10-4.89)$ & 1.000 \\
\hline & Health professionals & $17(28.8)$ & $6(14.6)$ & 1 & \\
\hline \multirow{4}{*}{ Adverse effects of the vaccine } & Mass media & 17 (43.6) & $34(55.7)$ & $0.78(0.28-2.16)$ & 0.631 \\
\hline & User-generated content & $13(33.3)$ & $7(11.5)$ & $2.89(0.83-10.02)$ & 0.094 \\
\hline & Others & $0(0)$ & $6(9.8)$ & - & 0.138 \\
\hline & Health professionals & $9(23.1)$ & $14(23.0)$ & 1 & \\
\hline \multirow{4}{*}{$\begin{array}{l}\text { Recommendations for } \\
\text { pregnancy }^{b}\end{array}$} & Mass media & $23(56.1)$ & $28(47.5)$ & $0.63(0.23-1.70)$ & 0.366 \\
\hline & User-generated content & $2(4.9)$ & $18(30.5)$ & $0.09(0.02-0.46)$ & 0.002 \\
\hline & Others & $3(7.3)$ & $3(5.1)$ & $0.77(0.13-4.66)$ & 1.000 \\
\hline & Health professionals & $13(31.7)$ & $10(16.9)$ & 1 & \\
\hline \multirow{4}{*}{$\begin{array}{l}\text { Recommendations for } \\
\text { children }{ }^{c}\end{array}$} & Mass media & 19 (57.6) & $32(47.8)$ & $0.54(0.20-1.47)$ & 0.232 \\
\hline & User-generated content & $0(0)$ & $20(29.9)$ & - & 0.000 \\
\hline & Others & $2(6.0)$ & $4(6.0)$ & $0.46(0.07-3.02)$ & 0.651 \\
\hline & Health professionals & $12(36.4)$ & $11(16.4)$ & 1 & \\
\hline \multirow{4}{*}{$\begin{array}{l}\text { Recommendations for people } \\
\text { aged } 60 / 65 \text { years or older }\end{array}$} & Mass media & $19(50.0)$ & $32(51.6)$ & $0.46(0.17-1.24)$ & 0.124 \\
\hline & User-generated content & $2(5.3)$ & $18(29.0)$ & - & 0.002 \\
\hline & Others & $4(10.5)$ & $2(3.2)$ & $1.54(0.23-10.15)$ & 1.000 \\
\hline & Health professionals & $13(34.2)$ & $10(16.1)$ & 1 & \\
\hline \multirow{4}{*}{$\begin{array}{l}\text { Recommendations for people } \\
\text { with chronic lung diseases }\end{array}$} & Mass media & $11(52.4)$ & $40(50.6)$ & $0.99(0.29-3.27)$ & 0.987 \\
\hline & User-generated content & $2(9.5)$ & $18(22.8)$ & $0.4(0.07-2.34)$ & 0.421 \\
\hline & Others & $3(14.3)$ & $3(3.8)$ & $3.6(0.55-23.65)$ & 0.305 \\
\hline & Health professionals & $5(23.8)$ & $18(22.8)$ & 1 & \\
\hline \multirow{4}{*}{$\begin{array}{l}\text { Recommendations for people } \\
\text { with chronic cardiovascular } \\
\text { disease }\end{array}$} & Mass media & $12(60.0)$ & $39(48.8)$ & $1.46(0.42-5.14)$ & 0.762 \\
\hline & User-generated content & $2(10.0)$ & $18(22.5)$ & $0.53(0.09-3.24)$ & 0.669 \\
\hline & Others & $2(10.0)$ & $4(5.0)$ & $2.38(0.32-17.74)$ & 0.575 \\
\hline & Health professionals & $4(20.0)$ & $19(23.8)$ & 1 & \\
\hline \multirow{4}{*}{$\begin{array}{l}\text { Recommendations for people } \\
\text { with cancer }\end{array}$} & Mass media & $9(64.3)$ & $42(48.8)$ & $1.43(0.35-5.86)$ & 0.743 \\
\hline & User-generated content & $1(7.1)$ & $19(22.1)$ & $0.35(0.04-3.67)$ & 0.611 \\
\hline & Others & $1(7.1)$ & $5(5.8)$ & $1.33(0.11-15.71)$ & 1.000 \\
\hline & Health professionals & $3(21.4)$ & $20(23.3)$ & 1 & \\
\hline
\end{tabular}


Table 6. Cont.

\begin{tabular}{|c|c|c|c|c|c|}
\hline $\begin{array}{l}\text { Information Regarding } \\
\text { Influenza Vaccine }\end{array}$ & Type of Authorship & $\begin{array}{l}\text { Available, } \\
n(\%)\end{array}$ & $\begin{array}{c}\text { Unavailable, } \\
n(\%)\end{array}$ & OR $(95 \% \mathrm{CI})^{\mathrm{a}}$ & $p$ \\
\hline \multirow{4}{*}{$\begin{array}{l}\text { Recommendations for people } \\
\text { with obesity }\end{array}$} & Mass media & $9(69.2)$ & $42(48.3)$ & $1.43(0.35-5.86)$ & 0.743 \\
\hline & User-generated content & $0(0)$ & $20(23.0)$ & - & 0.236 \\
\hline & Others & $1(7.7)$ & $5(5.7)$ & $1.33(0.11-15.71)$ & 1.000 \\
\hline & Health professionals & $3(23.1)$ & $20(23.0)$ & 1 & \\
\hline \multirow{4}{*}{$\begin{array}{l}\text { Recommendations for } \\
\text { healthcare workers }\end{array}$} & Mass media & $12(66.7)$ & $39(47.5)$ & $1.46(0.42-5.14)$ & 0.762 \\
\hline & User-generated content & $0(0)$ & $20(24.4)$ & - & 0.111 \\
\hline & Others & $2(11.1)$ & $4(4.9)$ & $2.38(0.32-17.74)$ & 0.575 \\
\hline & Health professionals & $4(22.2)$ & $19(23.2)$ & 1 & \\
\hline \multirow{4}{*}{$\begin{array}{l}\text { Recommendations for people } \\
\text { with HIV }{ }^{d}\end{array}$} & Mass media & $7(77.8)$ & $44(48.4)$ & $3.5(0.41-30.26)$ & 0.422 \\
\hline & User-generated content & $0(0)$ & $20(22.0)$ & - & 1.000 \\
\hline & Others & $1(11.1)$ & $5(5.5)$ & $4.4(0.23-82.98)$ & 0.377 \\
\hline & Health professionals & $1(11.1)$ & $22(24.1)$ & 1 & \\
\hline \multirow{4}{*}{$\begin{array}{l}\text { Recommendations for people } \\
\text { with chronic kidney disease }\end{array}$} & Mass media & $5(71.4)$ & $46(49.5)$ & $2.39(0.26-21.72)$ & 0.659 \\
\hline & User-generated content & $1(14.3)$ & $19(20.4)$ & $1.16(0.07-19.79)$ & 1.000 \\
\hline & Others & $0(0)$ & $6(6.5)$ & - & 1.000 \\
\hline & Health professionals & $1(14.3)$ & $22(23.7)$ & 1 & \\
\hline \multirow{4}{*}{$\begin{array}{l}\text { Recommendations for people } \\
\text { with diabetes mellitus }\end{array}$} & Mass media & $13(61.8)$ & $38(48.1)$ & $1.63(0.47-5.66)$ & 0.558 \\
\hline & User-generated content & $2(9.5)$ & $18(22.8)$ & $0.53(0.09-3.24)$ & 0.669 \\
\hline & Others & $2(9.5)$ & $4(5.1)$ & $2.38(0.32-17.74)$ & 0.575 \\
\hline & Health professionals & $4(19.1)$ & $19(24.0)$ & 1 & \\
\hline \multirow{4}{*}{$\begin{array}{l}\text { Recommendations for all } \\
\text { people older than } 6 \text { months }\end{array}$} & Mass media & $3(27.3)$ & $48(53.9)$ & $0.14(0.03-0.62)$ & 0.008 \\
\hline & User-generated content & $0(0)$ & $20(22.5)$ & - & 0.010 \\
\hline & Others & $1(9.1)$ & $5(5.6)$ & $0.46(0.05-4.67)$ & 0.647 \\
\hline & Health professionals & $7(63.6)$ & $16(18.0)$ & 1 & \\
\hline \multirow{4}{*}{ Costs of the vaccine } & Mass media & $11(61.0)$ & $40(48.8)$ & $0.99(0.29-3.27)$ & 0.987 \\
\hline & User-generated content & $1(5.6)$ & $19(23.2)$ & $0.19(0.02-1.78)$ & 0.192 \\
\hline & Others & $1(5.6)$ & $5(6.1)$ & $0.72(0.07-7.66)$ & 1.000 \\
\hline & Health professionals & $5(27.8)$ & $18(21.9)$ & 1 & \\
\hline \multirow{4}{*}{ Description of the dosage } & Mass media & $9(64.3)$ & $42(48.8)$ & $0.77(0.23-2.63)$ & 0.679 \\
\hline & User-generated content & $0(0)$ & $20(23.3)$ & - & 0.051 \\
\hline & Others & $0(0)$ & $6(7.0)$ & - & 0.553 \\
\hline & Health professionals & $5(35.7)$ & $18(20.9)$ & 1 & \\
\hline \multirow{4}{*}{$\begin{array}{l}\text { Hoaxes and conspiracy } \\
\text { theories }\end{array}$} & Mass media & $2(10.5)$ & $49(60.5)$ & $0.27(0.04-1.75)$ & 0.170 \\
\hline & User-generated content & $14(73.7)$ & $6(7.4)$ & $15.56(3.32-72.93)$ & 0.000 \\
\hline & Others & $0(0)$ & $6(7.4)$ & - & 1.000 \\
\hline & Health professionals & $3(15.8)$ & $20(24.7)$ & 1 & \\
\hline
\end{tabular}

${ }^{\mathrm{a}}$ OR $(95 \% \mathrm{CI})$ : odds ratio (95\% confidence interval). ${ }^{\mathrm{b}}$ Recommendations for pregnancy (from 13 weeks of gestation or in any trimester of pregnancy). ${ }^{c}$ Recommendations for children of 6 months to $2 / 5 / 6 / 10$ years. ${ }^{d}$ HIV: human immunodeficiency virus.

3.6. RQ 6: Is There Any Relationship between the Country of Publication of the Video and the Year of Publication, Number of Views/Likes/Dislikes/Comments, Duration, Type of Publication, Positive Tone of the Message, and Information Discussed Regarding the Influenza Vaccine?

According to the country of publication, videos published in Spain, in comparison to those from Hispanic America, presented significant differences in the positive tone of their message (OR: 0.19 (95\% CI: 0.06-0.61)) (Table 7), evidence for the benefits of vaccination (OR: 0.32 (95\% CI: 0.10-0.99)), and information on recommendations to vaccinate children. 
In addition, significant differences were observed when comparing videos published from the United States of America (USA) with those from Hispanic America regarding the consistency of their recommendation to vaccinate children (OR: 0.11 (95\% CI: 0.01-0.88)), people aged 60/65 or older (OR: 0.1 (95\% CI: 0.01-0.83)), and people with chronic cardiovascular disease. A higher number of hoaxes was detected in videos from Spain and the USA compared to those from Hispanic American countries (Table 8). No other significant associations were found $(p>0.05)$.

Table 7. Country of publication and tone of the message.

\begin{tabular}{|c|c|c|c|c|c|}
\hline Tone & Country of Publication & $\begin{array}{c}\text { Available, } \\
n(\%)\end{array}$ & $\begin{array}{c}\text { Unavailable, } \\
n(\%)\end{array}$ & OR $(95 \% \mathrm{CI})^{a}$ & $p$ \\
\hline \multirow{4}{*}{$\begin{array}{c}\text { Positive tone of the } \\
\text { message }\end{array}$} & Spain & $6(9.2)$ & $10(28.6)$ & $0.19(0.06-0.61)$ & 0.003 \\
\hline & United States of America & $7(10.8)$ & $4(11.4)$ & $0.56(0.15-2.16)$ & 0.399 \\
\hline & Others/Unknown & $2(3.1)$ & $5(14.3)$ & $0.13(0.02-0.73)$ & 0.009 \\
\hline & Hispanic American countries & $50(76.9)$ & $16(45.7)$ & 1 & \\
\hline
\end{tabular}

a OR (95\% CI): odds ratio (95\% confidence interval).

Table 8. Country of publication and information discussed regarding the influenza vaccine.

\begin{tabular}{|c|c|c|c|c|c|}
\hline $\begin{array}{l}\text { Information Regarding } \\
\text { Influenza Vaccine }\end{array}$ & Country of Publication & $\begin{array}{l}\text { Available, } \\
n(\%)\end{array}$ & $\begin{array}{l}\text { Unavailable, } \\
n(\%)\end{array}$ & OR $(95 \% C I)^{a}$ & $p$ \\
\hline \multirow{4}{*}{ Benefits of the vaccine } & Spain & $6(10.2)$ & $10(24.4)$ & $0.32(0.10-0.99)$ & 0.044 \\
\hline & United States of America & $8(13.6)$ & $3(7.3)$ & $1.43(0.35-5.90)$ & 0.625 \\
\hline & Others/Unknown & $2(3.4)$ & $5(12.2)$ & $0.21(0.04-1.19)$ & 0.060 \\
\hline & Hispanic American countries & $43(72.9)$ & $23(56.1)$ & 1 & \\
\hline \multirow{4}{*}{ Adverse effects of the vaccine } & Spain & $8(20.5)$ & $8(13.1)$ & $1.75(0.58-5.26)$ & 0.319 \\
\hline & United States of America & $5(12.8)$ & $6(9.8)$ & $1.46(0.40-5.29)$ & 0.567 \\
\hline & Others/Unknown & $2(5.1)$ & $5(8.2)$ & $0.7(0.13-3.89)$ & 0.684 \\
\hline & Hispanic American countries & $24(61.5)$ & $42(68.9)$ & 1 & \\
\hline \multirow{4}{*}{$\begin{array}{l}\text { Recommendations for } \\
\text { pregnancy }^{b}\end{array}$} & Spain & $4(9.8)$ & $12(20.3)$ & $0.33(0.09-1.14)$ & 0.073 \\
\hline & United States of America & $4(9.8)$ & $7(11.9)$ & $0.57(0.15-2.14)$ & 0.405 \\
\hline & Others/Unknown & $0(0)$ & $7(11.9)$ & - & 0.012 \\
\hline & Hispanic American countries & $33(80.5)$ & $33(55.9)$ & 1 & \\
\hline \multirow{4}{*}{$\begin{array}{l}\text { Recommendations for } \\
\text { children }^{c}\end{array}$} & Spain & $0(0)$ & $16(23.9)$ & - & 0.000 \\
\hline & United States of America & $1(3.0)$ & $10(14.9)$ & $0.11(0.01-0.88)$ & 0.015 \\
\hline & Others/Unknown & $0(0)$ & $7(10.4)$ & - & 0.015 \\
\hline & Hispanic American countries & $32(97.0)$ & $34(50.7)$ & 1 & \\
\hline \multirow{4}{*}{$\begin{array}{l}\text { Recommendations for people } \\
\text { aged } 60 / 65 \text { or older }\end{array}$} & Spain & $4(10.5)$ & $12(19.4)$ & $0.33(0.09-1.14)$ & 0.073 \\
\hline & United States of America & $1(2.6)$ & $10(16.1)$ & $0.1(0.01-0.83)$ & 0.012 \\
\hline & Others/Unknown & $0(0)$ & $7(11.3)$ & - & 0.012 \\
\hline & Hispanic American countries & $33(86.8)$ & $33(53.2)$ & 1 & \\
\hline \multirow{4}{*}{$\begin{array}{l}\text { Recommendations for people } \\
\text { with chronic lung diseases }\end{array}$} & Spain & $2(9.5)$ & $14(17.7)$ & $0.38(0.08-1.85)$ & 0.219 \\
\hline & United States of America & $1(4.8)$ & $10(12.7)$ & $0.27(0.03-2.24)$ & 0.198 \\
\hline & Others/Unknown & $0(0)$ & $7(8.9)$ & - & 0.114 \\
\hline & Hispanic American countries & $18(85.7)$ & $48(60.8)$ & 1 & \\
\hline \multirow{4}{*}{$\begin{array}{l}\text { Recommendations for people } \\
\text { with chronic cardiovascular } \\
\text { disease }\end{array}$} & Spain & $2(10.0)$ & $14(17.5)$ & $0.38(0.08-1.85)$ & 0.219 \\
\hline & United States of America & $0(0)$ & $11(13.8)$ & - & 0.049 \\
\hline & Others/Unknown & $0(0)$ & $7(8.8)$ & - & 0.114 \\
\hline & Hispanic American countries & $18(90.0)$ & $48(60.0)$ & 1 & \\
\hline
\end{tabular}


Table 8. Cont.

\begin{tabular}{|c|c|c|c|c|c|}
\hline $\begin{array}{l}\text { Information Regarding } \\
\text { Influenza Vaccine }\end{array}$ & Country of Publication & $\begin{array}{c}\text { Available, } \\
n(\%)\end{array}$ & $\begin{array}{c}\text { Unavailable, } \\
n(\%)\end{array}$ & OR $(95 \% \mathrm{CI})^{\mathrm{a}}$ & $p$ \\
\hline \multirow{4}{*}{$\begin{array}{l}\text { Recommendations for people } \\
\text { with cancer }\end{array}$} & Spain & $1(7.1)$ & $15(17.4)$ & $0.27(0.03-2.25)$ & 0.203 \\
\hline & United States of America & $0(0)$ & $11(12.8)$ & - & 0.109 \\
\hline & Others/Unknown & $0(0)$ & $7(8.1)$ & - & 0.198 \\
\hline & Hispanic American countries & $13(92.9)$ & $53(61.6)$ & 1 & \\
\hline \multirow{4}{*}{$\begin{array}{l}\text { Recommendations for people } \\
\text { with obesity }\end{array}$} & Spain & $0(0)$ & $16(18.4)$ & - & 0.054 \\
\hline & United States of America & $0(0)$ & $11(12.6)$ & - & 0.109 \\
\hline & Others/Unknown & $0(0)$ & $7(8.0)$ & - & 0.198 \\
\hline & Hispanic American countries & $13(100)$ & $53(60.9)$ & 1 & \\
\hline \multirow{4}{*}{$\begin{array}{l}\text { Recommendations for } \\
\text { healthcare workers }\end{array}$} & Spain & $3(16.7)$ & $13(15.9)$ & $0.79(0.19-3.12)$ & 0.732 \\
\hline & United States of America & $0(0)$ & $11(13.4)$ & - & 0.080 \\
\hline & Others/Unknown & $0(0)$ & $7(8.5)$ & - & 0.159 \\
\hline & Hispanic American countries & $15(83.3)$ & $51(62.2)$ & 1 & \\
\hline \multirow{4}{*}{$\begin{array}{l}\text { Recommendations for people } \\
\text { with HIV }{ }^{d}\end{array}$} & Spain & $0(0)$ & $16(17.6)$ & - & 0.194 \\
\hline & United States of America & $0(0)$ & $11(12.1)$ & - & 0.343 \\
\hline & Others/Unknown & $0(0)$ & $7(7.7)$ & - & 0.586 \\
\hline & Hispanic American countries & $9(100)$ & $57(62.6)$ & 1 & \\
\hline \multirow{4}{*}{$\begin{array}{l}\text { Recommendations for people } \\
\text { with chronic kidney disease }\end{array}$} & Spain & $0(0)$ & $16(17.2)$ & - & 0.336 \\
\hline & United States of America & $0(0)$ & $11(11.8)$ & - & 0.584 \\
\hline & Others/Unknown & $0(0)$ & $7(7.5)$ & - & 1.000 \\
\hline & Hispanic American countries & $7(100)$ & $59(63.5)$ & 1 & \\
\hline \multirow{4}{*}{$\begin{array}{l}\text { Recommendations for people } \\
\text { with diabetes mellitus }\end{array}$} & Spain & $2(9.5)$ & $14(17.7)$ & $0.38(0.08-1.85)$ & 0.219 \\
\hline & United States of America & $1(4.8)$ & $10(12.7)$ & $0.27(0.03-2.24)$ & 0.198 \\
\hline & Others/Unknown & $0(0)$ & $7(8.9)$ & - & 0.114 \\
\hline & Hispanic American countries & $18(85.7)$ & $48(60.8)$ & 1 & \\
\hline \multirow{4}{*}{$\begin{array}{l}\text { Recommendations for all } \\
\text { people older than } 6 \text { months }\end{array}$} & Spain & $1(9.1)$ & $15(16.9)$ & $0.42(0.05-3.59)$ & 0.421 \\
\hline & United States of America & $1(9.1)$ & $10(11.2)$ & $0.63(0.07-5.56)$ & 0.679 \\
\hline & Others/Unknown & $0(0)$ & $7(7.9)$ & - & 0.300 \\
\hline & Hispanic American countries & $9(81.8)$ & $57(64.0)$ & 1 & \\
\hline \multirow{4}{*}{ Costs of the vaccine } & Spain & $1(5.6)$ & $15(18.3)$ & $0.19(0.02-1.57)$ & 0.093 \\
\hline & United States of America & $0(0)$ & $11(13.4)$ & - & 0.058 \\
\hline & Others/Unknown & $0(0)$ & $7(8.5)$ & - & 0.128 \\
\hline & Hispanic American countries & $17(94.4)$ & $49(59.8)$ & 1 & \\
\hline \multirow{4}{*}{ Description of the dosage } & Spain & $0(0)$ & $16(18.6)$ & - & 0.054 \\
\hline & United States of America & $1(7.1)$ & $10(11.6)$ & $0.41(0.05-3.48)$ & 0.402 \\
\hline & Others/Unknown & $0(0)$ & $7(8.1)$ & - & 0.198 \\
\hline & Hispanic American countries & $13(92.9)$ & $53(61.6)$ & 1 & \\
\hline \multirow{4}{*}{$\begin{array}{l}\text { Hoaxes and conspiracy } \\
\text { theories }\end{array}$} & Spain & $6(31.6)$ & $10(12.4)$ & $6.0(1.61-22.34)$ & 0.004 \\
\hline & United States of America & $4(21.0)$ & $7(8.6)$ & $5.71(1.29-25.29)$ & 0.031 \\
\hline & Others/Unknown & $3(15.8)$ & $4(4.9)$ & $7.5(1.35-41.72)$ & 0.036 \\
\hline & Hispanic American countries & $6(31.6)$ & $60(74.1)$ & 1 & \\
\hline
\end{tabular}

${ }^{\mathrm{a}}$ OR $(95 \% \mathrm{CI})$ : odds ratio (95\% confidence interval). ${ }^{\mathrm{b}}$ Recommendations for pregnancy (from 13 weeks of gestation or in any trimester of pregnancy). ${ }^{c}$ Recommendations for children of 6 months to $2 / 5 / 6 / 10$ years. ${ }^{d}$ HIV: human immunodeficiency virus. 


\section{Discussion}

This study is the first to analyze the characteristics of YouTube videos that provide information in Spanish about the influenza vaccine by considering the three terms used in Spanish-speaking countries to refer to this virus (gripe, influenza, and gripa). In this way, we obtained results with greater validity at an international level than the only other published research of this type (to our knowledge), in which only videos obtained using the term "vacuna gripe" were evaluated [18].

The majority of the videos $(65.0 \%)$ had a positive tone toward the vaccine's use, which contrasts with the results of Yiannakoulias et al. [11], who evaluated 141 videos in English about the vaccine and observed that only $16.3 \%$ were in favor of it. This disparity according to language coincides with studies on other vaccines, such as those for human papillomavirus, in which a mostly positive tone was detected in more than three-quarters of the videos in Spanish [24], while in English, positions against the vaccine's use were the most frequent (51.7\%) [15].

The median number of views detected $(10,553.5)$ was also much higher than those found by Yiannakoulias et al. (67.5) [11]. This may be because this author analyzed a sample of selected videos in the order in which they appeared in the YouTube search results. In addition, since $36.0 \%$ of the videos corresponded to news previously broadcast by mass media, they were potentially seen by many more people than those who accessed the version on YouTube.

In just over half of the videos (51.0\%), the type of authorship corresponded to mass media, which is consistent with the results found for Spanish videos on the Bexsero vaccine (45.2\%) [25] but differs from the results of Tuells et al., who observed that only $14.1 \%$ of the Spanish videos on human papillomavirus vaccines were produced by mass media [24].

Although the main information provided corresponded to the benefits of the vaccine, a fact recognized worldwide [26], in $41.0 \%$ of the videos, a positive tone was not found, which indicates that the information in YouTube videos regarding the flu vaccine is often incomplete. This deficiency of information in YouTube videos that focus on the influenza vaccine can be confirmed by observing the low frequency of certain recommendations of the World Health Organization (WHO) [27] adopted in Spain [28], the USA [29], and Hispanic American countries [30,31], such as recommendations to vaccinate healthcare workers annually to reduce the risk of acquiring the influenza and transmitting it to their patients $[28,29,32]$. Similarly, other WHO recommendations adopted in such countries [27-31], such as vaccinating people over 65 years of age, did not appear in half of the videos, even if the recommendation is described as such, or in the context of expanding vaccination in certain countries by including a recommendation to vaccinate people over 60 years of age [30,31] or the entire population over 6 months of age [29]. Something similar was observed with the recommendation to vaccinate during any trimester of pregnancy, which did not appear in half of the videos, and the recommendation to vaccinate pregnant women only from the second trimester in certain countries [33]. For all these reasons, influenza vaccination coverage in Spanish-speaking countries can be improved $[31,34,35]$. Indeed, among other factors, vaccination coverage among healthcare workers is usually less than $46 \%$ [31,35], less than $55 \%$ in those over $60 / 65$ years olf $[31,34,35]$, and less than $41 \%$ in pregnant women [31,35]. Moreover, the information available on YouTube can influence the vaccination habits of its users [3]. Therefore, a possible measure to improve such coverage could be to use YouTube to officially disseminate these recommendations. Indeed, several scientific societies, such as the Spanish Association of Vaccinology and the Spanish Society of Preventive Medicine and Public Health, have proposed to use social networks to disseminate such indications and raise awareness of the importance of this vaccine as a strategy to increase influenza vaccination coverage [4]. The implementation and evaluation of the effectiveness of this measure could be the subject of future research.

The differences detected in the tone of the message, according to type of authorship, are congruent with other studies that have analyzed the information on YouTube about vaccines in general, in which the videos of health professionals have a more positive 
tone [3]. Likewise, the fact that these videos are more likely to provide reliable information confirms what other authors have described [13].

The finding that videos made by health professionals, compared to user-generated content, produce less interaction between YouTube users in terms of likes could be explained by the phenomenon called confirmation bias, which leads people to favor information that confirms their beliefs [36]. These behaviors create what is called an "echo chamber" in the new media [37], and our results confirm this feature.

On the other hand, the fact that videos published in Hispanic America were found to be more likely to provide certain vaccination recommendations, as well as a lower number of hoaxes, justifies promoting, among users residing in Hispanic American countries, the consultation of videos specifically produced in such countries by health professionals when they search on YouTube for information in Spanish about the influenza vaccine. Likewise, Spanish health professionals should be urged to publish information about this vaccine on YouTube, alluding to its benefits, counteracting the hoaxes, and making videos with a pro-vaccination tone to help change the tendency where videos produced in Spain less frequently have a positive tone, describe the benefits of the vaccine with less frequency, and provide a greater number of hoaxes than those in Hispanic American countries.

Hoaxes, or conspiracy theories, were detected in $19.0 \%$ of the videos. This represents a very worrying and novel finding (since previous research on the information available on YouTube about the influenza vaccine had not evaluated this aspect $[11,18])$. The dissemination of misinformation can cause fear and ultimately diminish the application of preventive measures $[38,39]$, mainly among non-medically educated users for whom it is difficult to judge the reliability of health information online [38]. Perhaps this reason is why the WHO website provides information to refute the following five myths: "influenza is not serious so I don't need the vaccine"; "the influenza vaccine can give me the flu"; "the influenza vaccine can cause severe side effects"; "I had the vaccine and still got the flu, so it doesn't work"; and "I am pregnant so I shouldn't get the influenza vaccine" [40].

However, on the basis of our findings, there is an urgent need for the WHO to counteract many more hoaxes. In addition, our findings could be used to guide the implementation of educational campaigns to correct misinformation about influenza vaccine in Spanish. In any case, to combat misinformation in YouTube, more strategies must be adopted, such as increasing editorial control within the platform [41], monitoring the spread of misinformation about vaccinations on YouTube, and encouraging governmental/academic organizations and new media to work together to fight false beliefs about vaccines [8].

The methodology used in this study is similar to that used by other authors [3,8, $11,13,15,16,19-21,24,41]$, and the limitations are those intrinsic to the Internet. In this type of infodemiological research $[9,10]$, the information available at any given time is analyzed $[3,8,11,13-16,18-21,24,41]$; however, the information online is constantly changing. In addition, the search terms were chosen by the authors under the assumption that a Spanish-speaking user would use one of them to perform simple searches on YouTube regarding influenza vaccine. The number of videos evaluated, although somewhat smaller than that used by some other authors (142) [16], was the same as, or greater than, that used in most studies of this type [13,14,19-21], in which 100 videos or less were included. In any case, our sample was able to obtain significant results.

\section{Conclusions}

This study shows that information on YouTube about the influenza vaccine is usually not very complete and that it differs according to the type of authorship and country of publication. Our findings suggest that Spanish health professionals should be more engaged in establishing a YouTube presence in order to provide reliable information, publishing pro-vaccination videos to respond to questions of the public about influenza vaccine and its hoaxes/conspiracy theories. Moreover, people residing in Hispanic America should be advised that, when looking for information related to this vaccine on YouTube, they should consult videos produced in Hispanic American countries by health professionals to obtain 
reliable information. These actions could be useful to allow Spanish-speaking citizens to make informed decisions about influenza vaccine so as to comply with vaccination recommendations.

Author Contributions: Conceptualization, I.H.-G.; methodology, I.H.-G. and T.G.-J.; formal analysis, I.H.-G.; writing—original draft preparation, I.H.-G. and T.G.-J.; writing—review and editing, I.H.-G. and T.G.-J. All authors have read and agreed to the published version of the manuscript.

Funding: This research received no external funding.

Institutional Review Board Statement: Not applicable.

Informed Consent Statement: Not applicable.

Data Availability Statement: Data is contained within the article.

Conflicts of Interest: The authors declare no conflict of interest.

\section{References}

1. Stokel-Walker, C. Covid-19: The doctors turned YouTubers. BMJ 2020, 369, m1563. [CrossRef] [PubMed]

2. Madathil, K.C.; Rivera-Rodriguez, A.J.; Greenstein, J.S.; Gramopadhye, A.K. Healthcare information on YouTube: A systematic review. Health Inform. J. 2015, 21, 173-194. [CrossRef] [PubMed]

3. Covolo, L.; Ceretti, E.; Passeri, C.; Boletti, M.; Gelatti, U. What arguments on vaccinations run through YouTube videos in Italy? A content analysis. Hum. Vaccin. Immunother. 2017, 13, 1693-1699. [CrossRef] [PubMed]

4. García, A.; Fernández Prada, M.; Aristegui, J.; Moreno, D.; Redondo, E.; Jimeno, I.; García Cenoz, M.; López Trigo, J.A. Documento de Actualización y Reflexión Sobre la Vacunación Antigripal en España, 1st ed.; Esmon Publicidad: Barcelona, Spain, 2018; ISBN 978-84-17394-12-7.

5. Yuksel, B.; Cakmak, K. Healthcare Information on YouTube: Pregnancy and COVID-19. Int. J. Gynaecol. Obstet. 2020. [CrossRef] [PubMed]

6. Gonsalves, G.; Staley, P. Panic, paranoia, and public health—The AIDS epidemic's lessons for Ebola. N. Engl. J. Med. 2014, 371, 2348-2349. [CrossRef] [PubMed]

7. Aquino, F.; Donzelli, G.; De Franco, E.; Privitera, G.; Lopalco, P.L.; Carducci, A. The web and public confidence in MMR vaccination in Italy. Vaccine 2017, 35 Pt B, 4494-4498. [CrossRef]

8. Donzelli, G.; Palomba, G.; Federigi, I.; Aquino, F.; Cioni, L.; Verani, M.; Carducci, A.; Lopalco, P. Misinformation on vaccination: A quantitative analysis of YouTube videos. Hum. Vaccin. Immunother. 2018, 14, 1654-1659. [CrossRef]

9. Eysenbach, G. Infodemiology: The epidemiology of (mis)information. Am. J. Med. 2002, 113, 763-765. [CrossRef]

10. Eysenbach, G. Infodemiology and infoveillance: Framework for an emerging set of public health informatics methods to analyze search, communication and publication behavior on the Internet. J. Med. Internet Res. 2009, 11, e11. [CrossRef]

11. Yiannakoulias, N.; Slavik, C.; Chase, M. Expressions of pro- and anti-vaccine sentiment on YouTube. Vaccine 2019, 37, 2057-2064. [CrossRef]

12. Ekram, S.; Debiec, K.E.; Pumper, M.A.; Moreno, M.A. Content and Commentary: HPV Vaccine and YouTube. J. Pediatr. Adolesc. Gynecol. 2019, 32, 153-157. [CrossRef] [PubMed]

13. Basch, C.H.; Zybert, P.; Reeves, R.; Basch, C.E. What do popular YouTube ${ }^{\mathrm{TM}}$ videos say about vaccines? Child Care Health Dev. 2017, 43, 499-503. [CrossRef] [PubMed]

14. Hernández-García, I.; Ragozzino, S.; Giménez-Júlvez, T. Characteristics of YouTube videos about the meningococcal B vaccine (4CMenB). Hum. Vaccin. Immunother. 2020, 16, 2513-2517. [CrossRef] [PubMed]

15. Briones, R.; Nan, X.; Madden, K.; Waks, L. When vaccines go viral: An analysis of HPV vaccine coverage on YouTube. Health Commun. 2012, 27, 478-485. [CrossRef] [PubMed]

16. Pandey, A.; Patni, N.; Singh, M.; Sood, A.; Singh, G. YouTube as a Source of Information on the H1N1 Influenza Pandemic. Am. J. Prev. Med. 2010, 38, e1-e3. [CrossRef]

17. Kallur, A.; Albalbissi, A.; Carillo-Martin, I.; Boonpheng, B.; Kallur, L.; Kherallah, Y.; Mahajan, A.; Mahapatra, S.; Mohan, K.; Mohan, P.; et al. Doctor YouTube's opinion on seasonal influenza: A critical appraisal of the information available to patients. Digit. Health 2020, 6. [CrossRef]

18. Hernández-García, I.; Tarancón-Cebrián, I. Characteristics of YouTube videos in Spanish about the influenza vaccine. An. Sist. Sanit. Navar. 2020, 43, 35-41. [CrossRef]

19. Basch, C.H.; Hillyer, G.C.; Meleo-Erwin, Z.C.; Jaime, C.; Mohlman, J.; Basch, C.E. Preventive Behaviors Conveyed on YouTube to Mitigate Transmission of COVID-19: Cross-Sectional Study. JMIR Public Health Surveill. 2020, 6, e18807. [CrossRef]

20. Mueller, S.M.; Jungo, P.; Cajacob, L.; Schwegler, S.; Itin, P.; Brandt, O. The Absence of Evidence is Evidence of Non-Sense: Cross-Sectional Study on the Quality of Psoriasis-Related Videos on YouTube and Their Reception by Health Seekers. J. Med. Internet Res. 2019, 21, e11935. [CrossRef] 
21. Basch, C.H.; Hillyer, G.C.; Zagnit, E.A.; Basch, C.E. YouTube coverage of COVID-19 vaccine development: Implications for awareness and uptake. Hum. Vaccin. Immunother. 2020. [CrossRef]

22. Hernández-García, I.; Giménez-Júlvez, T. Characteristics of YouTube Videos in Spanish on How to Prevent COVID-19. Int. J. Environ. Res. Public Health 2020, 17, 4671. [CrossRef] [PubMed]

23. Keelan, J.; Pavri-Garcia, V.; Tomlinson, G.; Wilson, K. YouTube as a source of information on immunization: A content analysis. JAMA 2007, 298, 2482-2484. [CrossRef] [PubMed]

24. Tuells, J.; Martínez-Martínez, P.J.; Duro-Torrijos, J.L.; Caballero, P.; Fraga-Freijeiro, P.; Navarro-López, V. Characteristics of the Videos in Spanish Posted on Youtube about Human Papillomavirus Vaccines. Rev. Esp. Salud Publica 2015, 89, 107-115. [CrossRef] [PubMed]

25. Hernández-García, I.; Fernández Porcel, C. Characteristics of YouTube ${ }^{\mathrm{TM}}$ videos in Spanish about the vaccine against meningococcus B. Vacunas 2018, 19, 37-43. [CrossRef]

26. Organización Mundial de la Salud. Preguntas y Respuestas Sobre Inmunización y Seguridad de las Vacunas. Available online: https:/ / www.who.int/features/qa/84/es/ (accessed on 10 November 2020).

27. Organización Mundial de la Salud. Gripe (Estacional). Available online: https://www.who.int/es/news-room/fact-sheets/ detail/influenza-(seasonal) (accessed on 9 November 2020).

28. Ministerio de Sanidad. Recomendaciones de Vacunación Frente a la Gripe: Temporada 2020-2021. Available online: https://www.mscbs.gob.es/profesionales/saludPublica/prevPromocion/vacunaciones/programasDeVacunacion/docs / Recomendaciones_vacunacion_gripe.pdf (accessed on 18 October 2020).

29. Grohskopf, L.A.; Alyanak, E.; Broder, K.R.; Walter, E.B.; Fry, A.M.; Jernigan, D.B. Prevention and Control of Seasonal Influenza with Vaccines: Recommendations of the Advisory Committee on Immunization Practices-United States, 2019-2020 Influenza Season. MMWR Recomm. Rep. 2019, 68, 1-21. [CrossRef]

30. Gentile, A.; Paget, J.; Bellei, N.; Torres, J.P.; Vazquez, C.; Laguna-Torres, V.A.; Plotkin, S. Influenza in Latin America: A report from the Global Influenza Initiative (GII). Vaccine 2019, 37, 2670-2678. [CrossRef]

31. Ropero-Álvarez, A.M.; El Omeiri, N.; Kurtis, H.J.; Danovaro-Holliday, M.C.; Ruiz-Matus, C. Influenza vaccination in the Americas: Progress and challenges after the 2009 A(H1N1) influenza pandemic. Hum. Vaccin. Immunother. 2016, 12, 2206-2214. [CrossRef]

32. World Health Organization. Vaccination of Health Care Workers Recommended. Available online: http://www.who.int/ immunization/policy/Immunization_routine_table4.pdf (accessed on 19 October 2020).

33. Ministerio de Salud de Chile. Campaña de Vacunación Contra la Influenza 2019: Ponle el Hombro al Invierno. Available online: https:/ / www.minsal.cl/vacunacion-contra-la-influenza/ (accessed on 12 November 2020).

34. Barratt, J.; Mishra, V.; Acton, M. Latin American Adult Immunisation Advocacy Summit: Overcoming regional barriers to adult vaccination. Aging Clin. Exp. Res. 2019, 31,339-344. [CrossRef]

35. Ministerio de Sanidad. Coberturas de Vacunación: Datos Estadísticos. Available online: https://www.mscbs.gob.es/ profesionales/saludPublica/prevPromocion/vacunaciones/calendario-y-coberturas/coberturas/home.htm (accessed on 14 November 2020).

36. Thomson, A.; Watson, M. Vaccine hesitancy: A vade mecum v1.0. Vaccine 2016, 34, 1989-1992. [CrossRef]

37. Dunn, A.G.; Leask, J.; Zhou, X.; Mandl, K.D.; Coiera, E. Associations between Exposure to and Expression of Negative Opinions about Human Papillomavirus Vaccines on Social Media: An Observational Study. J. Med. Internet Res. 2015, 17, e144. [CrossRef]

38. Cuan-Baltazar, J.; Muñoz-Perez, M.J.; Robledo-Vega, C.; Pérez-Zepeda, M.F.; Soto-Vega, E. Misinformation of COVID-19 on the internet: Infodemiology study. JMIR Public Health Surveill. 2020, 6, e18444. [CrossRef] [PubMed]

39. Rovetta, A.; Bhagavathula, A.S. COVID-19-related web search behaviors and infodemic attitudes in Italy: Infodemiological study. JMIR Public Health Surveill. 2020, 6, e19374. [CrossRef] [PubMed]

40. World Health Organization. 5 Myths about the Flu Vaccine. Available online: https://www.who.int/news-room/spotlight/ influenza-are-we-ready/5-myths-about-the-flu-vaccine (accessed on 27 August 2020).

41. Venkatraman, A.; Garg, N.; Kumar, N. Greater freedom of speech on Web 2.0 correlates with dominance of views linking vaccines to autism. Vaccine 2015, 33, 1422-1425. [CrossRef] [PubMed] 